\title{
BRACE ARRANGEMENT, NODE STIFFENING AND CONNECTION OF SPRINGS OF STEEL TUBULAR ARCH BRIDGES
}

\author{
RASPORED UKRUĆENJA, UKRUĆENJE ČVOROVA I VEZA S KRAJNJIM \\ OSLONCIMA ČELIČNIH CEVASTIH LUČNIH MOSTOVA
}

\author{
Philippe VAN BOGAERT
}

ORIGINALNI NAUČNI RAD

ORIGINAL SCIENTIFIC PAPER

UDK:624.21.014.2:620.178.3

doi:10.5937/GRMK1901003V

\section{INTRODUCTION}

Steel tubular arch bridges are highly appreciated for their aesthetical value and elegance. This is due to many factors, such as the curvature of members, tubes being considered more 'simple' than other sections, low surface area compared to equivalent open sections, smooth transition of light shading, avoidance of sharp edges between shaded and lighted surfaces and also more technical features. This has also contributed to the success of tubular structures in buildings, roofs, spatial structures, telescopes, transmission lines and masts and offshore structures [1]. In addition, tubular structures show high torsional stiffness, lower wind pressure and low weight.

However, the nodes are its counterparts. The junction of 3 or more intersecting tubes is complicated, both to design and to fabricate. In some bridges, the nodes are made from cast steel and then welded to connect the meeting tubes. Other showcases have welded nodes, requiring precise cutting of individual members as well as large use of welding material. The nodes are determining the costly character of tubular bridges and their degree of complexity. However, they also clearly show the transfer of forces between members. Hence, the elegance of this type of structures is highly determined by the flawless character of the connections of members.

Particular types of node are the arch springs. They are of paramount importance since they transfer the various reactions from the bridge superstructure to the abutments. The most important reaction is the arch thrust force together with the vertical reactions. Whether

Professor Em. Dr. Ing. Philippe Van Bogaert - Ghent University (Belgium) bending moments are transferred to the infrastructure at the arch springs depends on the use of hinges or clamping. The fabrication of hinges certainly is more complicated than complete clamping of arch springs. In most cases, the concept of the arch spring connections corresponds to clamping and bending moment transfer.

Since the torsional capacity and stiffness of circular sections are rather high, large torsion clamping may be expected. Experience has demonstrated that torsional clamping may not be entirely efficient and that small angular rotations may occur, in case of clamping by prestressing bars. As an alternative, clamping by steelconcrete connectors may be considered. This has recently been applied to 2 bridges, the general idea being to attribute a certain type of connector to resist one or several types of reactions. To underpin such connections, three preliminary experiments, including strip and stud connectors have been carried out to demonstrate the failure mechanisms. From the first loading a composite action of steel and concrete exists. Failure of strip connectors is due to exceeding compression of the surrounding concrete, followed by high pressure in the contact area between both materials and final failure due to yielding the steel strips as reinforcement of the composite cross-section. Failure of stud connectors occurred prematurely due to concrete splitting at the contact area of the stud shaft. This is avoided by normal reinforcement, provided it interacts with the studs. Application of the test results by scaling to the case of a recently built steel arch shows that its connection with internal headed studs does not contribute to torsion stiffness. However, scaling of the test results demonstrates that the arch spring almost behaves as in free torsion condition. 


\section{EXAMPLES OF RAILWAY TUBULAR BRIDGES}

\subsection{Merxem Street truss tubular arch}

The Merxem Street Bridge was built to carry the high-speed railway line from Brussels to Amsterdam and is located immediately to the North of the city of Antwerp [2]. It is part of the North-South link below the city of Antwerp. The crossing with Merxem Street is located inbetween two more important steel bridges across the Albert Canal and the ljzerlaan. They have spans of 117 and $56 \mathrm{~m}$ respectively.

At this particular site, the high-speed line is located parallel to domestic tracks. The latter cross the Merxem Street by a double vaulted brickwork arch, dating from 1910 and spanning the $18 \mathrm{~m}$ wide local road. The brickwork vaults are well preserved and show historic value. Since the building permit covered the whole North-South link, including large transformations of many listed heritage structures, special care had to be taken to preserve the function and the view on older structures. This was in particular the case for the Merxem bridges. Hence, both a functional and aesthetic bridge of a particular character, complying well with historic building had to be designed.

In view of these conditions, several alternatives have been considered for this bridge. Obviously, vaulted arches include heavy abutments and especially the view on the arch crown should be kept. Therefore, the span of the new bridge had to be sufficiently large in order not to hide these important parts. In addition, arches can be highly compatible with the basic function of the vaults. This almost excludes traditional beam bridges having a span of approximately $27 \mathrm{~m}$. A first type of alternative is to build a steel tied arch with slender lower chord. The disadvantage of this type resides in the higher level of the superstructure. The existing bridge being located below the tracks, a new structure of larger altitude disturbs the site in general. Hence, a structure below the tracks is to be preferred.

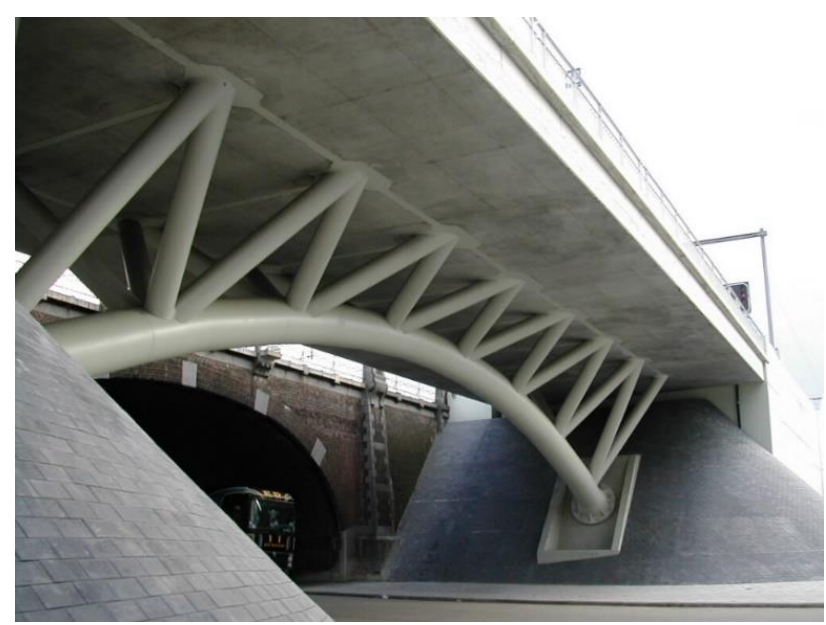

Figure 1. Merxem street tubular arch bridge
Since there are few fine examples of tubular arches, this type of structure could certainly be considered. The advantages are clear, provided the arch itself would consist of a single tube as can be seen in figure 1 . The horizontal distance of the single tube to the front of the brickwork reaches $8 \mathrm{~m}$, the interesting parts of the vaults being seen from the street level. In addition, the concrete deck is supported by inclined tubes, constituting members of a tubular truss. This arrangement also contributes to contrast with the massive nature of brickwork vaults. At the same time the modern steel truss, fabricated with modern welding processes renders a flawless shape, contrasting highly with the rough texture of old brickwork. This contrast of textures and shapes may be the best way of dealing with the challenges of combining old and new bridge structures.

\subsection{Woluwe Lane framed tubular arch bridge}

The Woluwe Lane Bridge allows 3 tracks to cross an important access road to the North of Brussels and for a new railway line, connecting Antwerp to Brussels airport [3], to enter the central reservation of the motorway. A particular characteristic of the bridge is that both lateral tracks are located at a distinctly higher level than the central track. This is because the latter has a different direction, since it is connected to a bend and is joining the Eastern circular railway around Brussels in the direction of the European Parliament. The location of this bridge made authorities to expect a particular design. Because of the difference of levels of the tracks and the subjacent roads, a tubular arch bridge was designed. This multi-level bridge consists of 2 almost parallel tubular arches, including tubular strut members, supporting the upper level tracks. The bridge deck of the central track is mostly suspended to both lateral arches. Due to the unbalanced action of the arches, the latter are slightly eccentric with respect to the upper level track axis. The arch span equals $78 \mathrm{~m}$, its rise being limited to $9 \mathrm{~m}$. Each concrete deck slab is supported by 2 tubular members, connected to an arch. Hence, these members show bending moments at the connections, the bending stresses being considerably larger than the stress due to axial compression. The Woluwe Lane Bridge is seen in Fig. 2.

As there is no direct connection of the arch top with the concrete upper decks, a short double strutting system has been provided. This connection is rather heavy and provides larger bending stiffness to the structure. Particular elements of this type of bridge are the arch springs, which may be hinged or clamped. In general, clamping of arches is easier to build, by using a base plate, connected to the concrete infrastructure by pre-stressing bars. Difficulties may arise in finding a workable manner to close the arches while controlling the effective arch thrust force. In the case of Woluwe Lane bridge, as the arches were assembled on site from 4 parts, the thrust force has been measured during jacking of adjacent parts. The steel tubes were welded on the building site, with appropriate procedures, to compensate welding shrinkage and allow fitting of the main tube parts. 


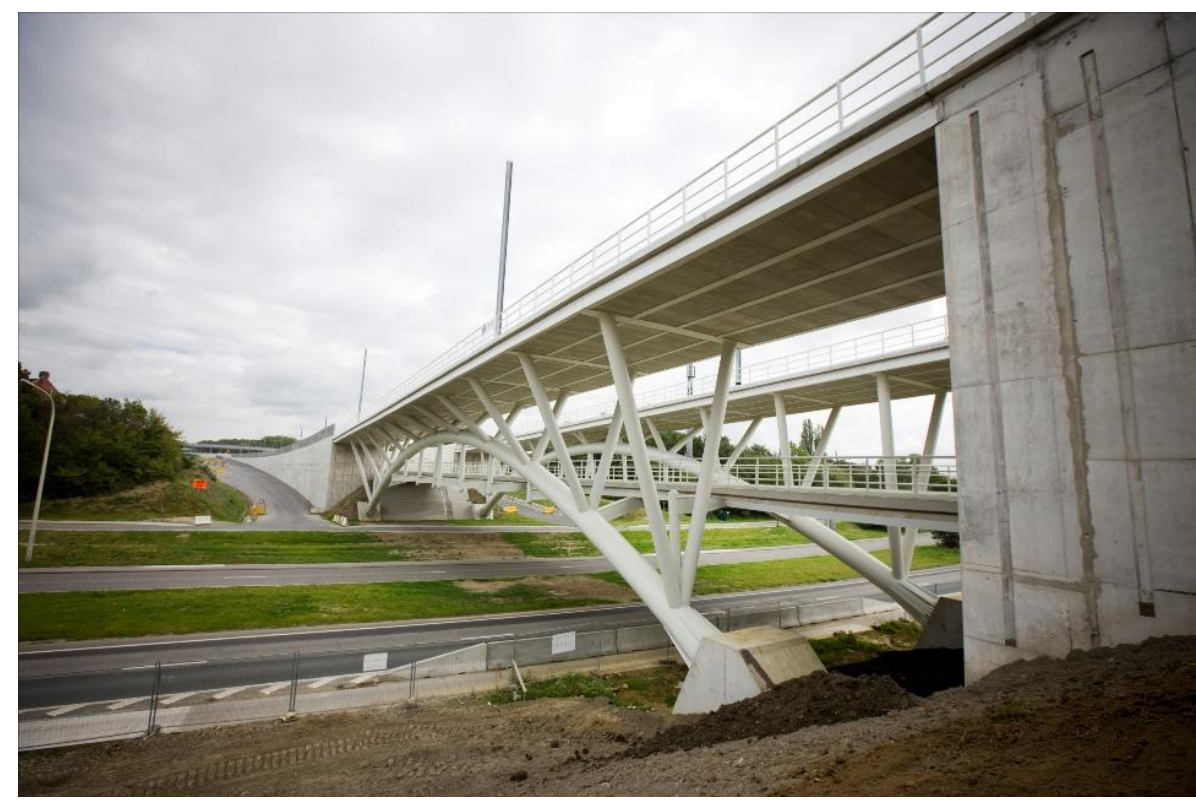

Figure 2. Woluwe Lane Bridge

\subsection{Truss versus frame arrangement}

Both bridges, commented before, have a different system to connect the upper floors with the main arch tube by bracing members. Typically, Merxem street bridge has a triangular in-plane arrangement of the braces whereas the brace members of Woluwe Lane Bridge constitute a framework with the floor deck and the main tube. Since both bridges have different span, a comparison of both structures is irrelevant. Hence, as a first step, the structure of Merxem Street was transformed into an equivalent bridge, having framed bracing tubes.

The definition of an equivalent bridge mainly applies to obtaining identical stress states in the various members of the structure, both the main arch tube and the bracing members. This can only be achieved by successive trial values of the characteristics of the tubes. In this, mainly the vertical loads due to dead weight and traffic loads have been considered. Thermal effects, as well as horizontal loads are not included in this comparison. The first type of loading has little consequence in this type of bridges, whereas the second type of loads in mainly diverted directly to the abutments. The bridges being considered are integral bridges, all concrete decks being fixed to the abutments.

Fig 3 shows the 2 types of structures, the triangular arrangement in the cross section being identical, since transverse connection of the deck slab to the single main tube has to be ensured. In addition, it should be mentioned that the values shown further are factored and concern ultimate limit state. Fig. 4 shows the comparison of normal forces and in-plane bending moments for both cases. Clearly, the envelope values of the normal arch compression force are quite different. Whereas for triangulated arrangement, the normal compression force is decreasing from the arch springs towards the top, in the framed arrangement, it remains rather constant. The former is due to the diversion of normal forces by the inclined braces. The arch compression force increases by some $27 \%$.

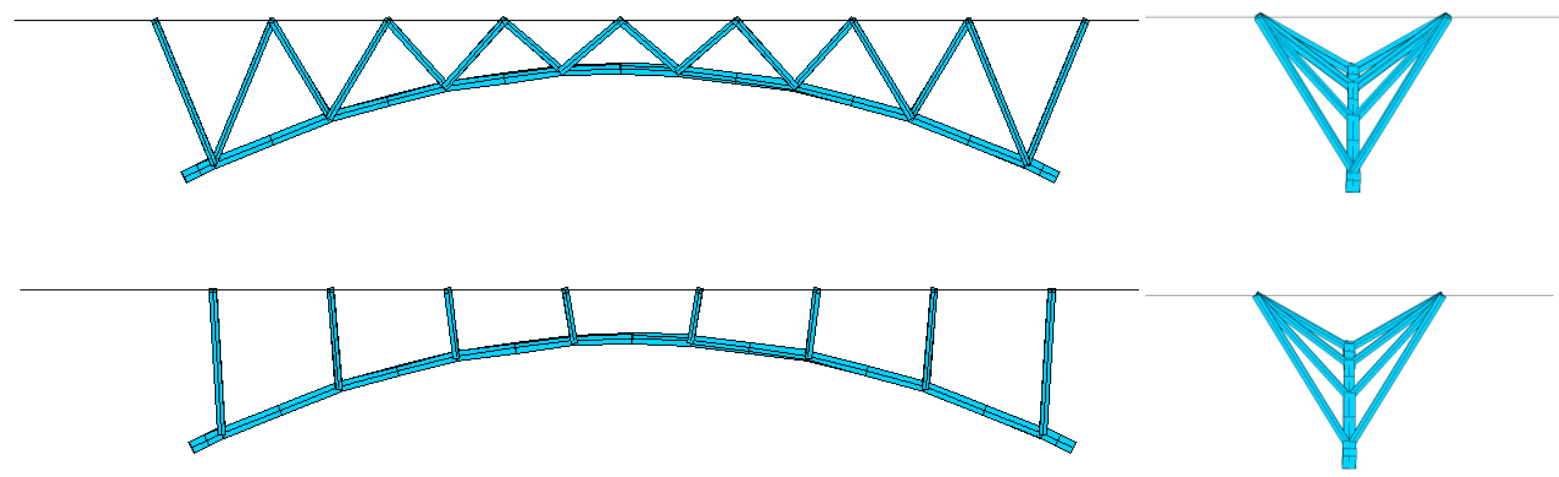

Figure 3. Triangulated (top) and frame arrangement of bracings (below) 

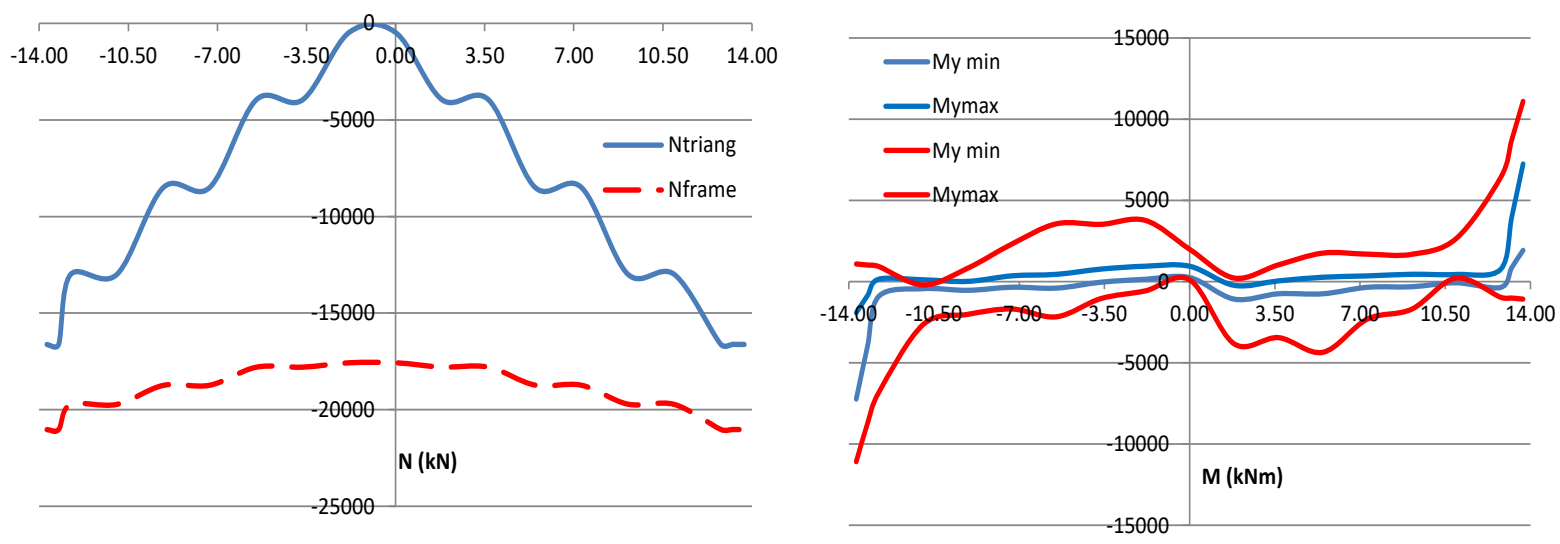

Figure 4.: Normal arch force (left) and bending moments (right)

Fig. 4 (right) also displays the in-plane bending moments in the arch tube. Maximum and minimum values have been derived. The diagrams are not entirely symmetrical, since asymmetrical loading is more relevant and there is no point in repeating calculations of both sides. In both cases the largest bending is found at the arch springs, where bending is increasing rapidly. Evidently the outside braces transfer larger bending to the main tube as the clamping moment is increased by some $50 \%$. Nevertheless, also in other parts of the main arch tube bending moments are larger for the frame arrangement than for the triangulated alternative. To have some idea about the magnitude, the most relevant bending moments are up till 6-times larger. In addition, other maximum values are appearing near quarter-span of the bridge, which is easily explained by the influence line of clamped arches. The general conclusions concerning the difference between both alternatives is that triangular brace arrangement performs distinctively higher, since the bending is reduced and the arch compression is lower near the arch top.

Similar diagrams are obtained for the brace tubes. However, the number of framed braces is half of the number in the triangulated alternative. On one hand, there is the observation that for triangular arrangement the number of brace members is double of that for the frame. On the other hand, vertical forces are deviated to inclined members, which are obviously larger than the original vertical force. Hence, in spite of the fact that there are twice as much braces for the triangular arrangement, the normal force is of the same order of magnitude.

In addition, the bending moments are seriously larger in the frame alternative. The multiplication factor may rise up to 6 for the most relevant values. However, the increase of stress resultants does not adequately quantify the most important characteristic, steel mass. The aforementioned comparison results in a difference of steel mass varying from 25 to $30 \%$ in favour of the triangulated alternative, which is in accordance with similar findings for tied arch bridges [4].

\section{NODES}

\subsection{K- and T-nodes}

Truss arrangement of braces, connecting a tubular arch to an upper bridge deck necessarily requires the nodes to be of the K-type. The latter is generally more complex than the simple T-type node, which is used in the frame alternative. This may constitute sufficient ground for the frame option. Both types of finished nodes are shown in Fig. 5.

The nodes constitute important discontinuities in the stress flow of the main arch tube. This causes stress concentrations near the weld toes of the nodes, mainly in the arch tube. These stress concentrations may seriously decrease the load carrying capacity of the structure, although they are not systematically considered at ultimate limit state of strength. In addition, the stress concentrations certainly reduce the fatigue strength, which mainly applies to road and railway bridges. Fatigue resistance, rather than ultimate limit state has determined the design of both the Merxem Street as well as the Woluwe Lane bridges.

The stress concentrations are due to heavy welding, the geometric discontinuity, the introduction of various stress resultants from the brace tubes and also the local deformation of the main arch tube member. The latter is the effect, shown in fig. 7 and is certainly due to bending moments at the nodes. Fig. 7 is the result of detailed FEM-modelling of several nodes as in [5]. Both normal force and bending moment from the smaller brace tube tend to disturb the circular cross-section of the tube, introducing a complex three-dimensional stress-state, since it introduces a circumferential bending of the tube wall.

A method has been developed to assess accurately the stress concentrations in tubular connections [5], including those introduced by shear and torsion. This method allows independent assessment of stress concentrations (and so-called hotspot stresses) due to the various member forces and moments, derived from simple wireframe calculation models. The advantage of this method resides in the fact that it may be applied to any type of K- or T-joints, whatever the complexity may be. 

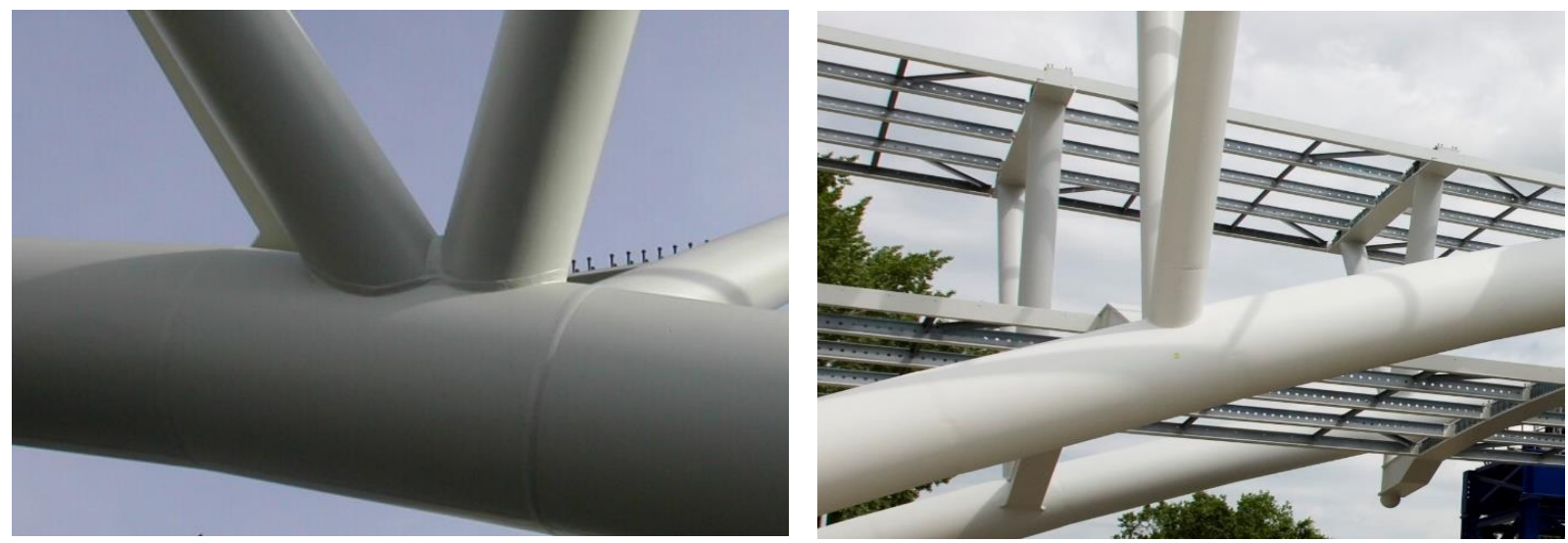

Figure 5. K-node (left) T-node (right)
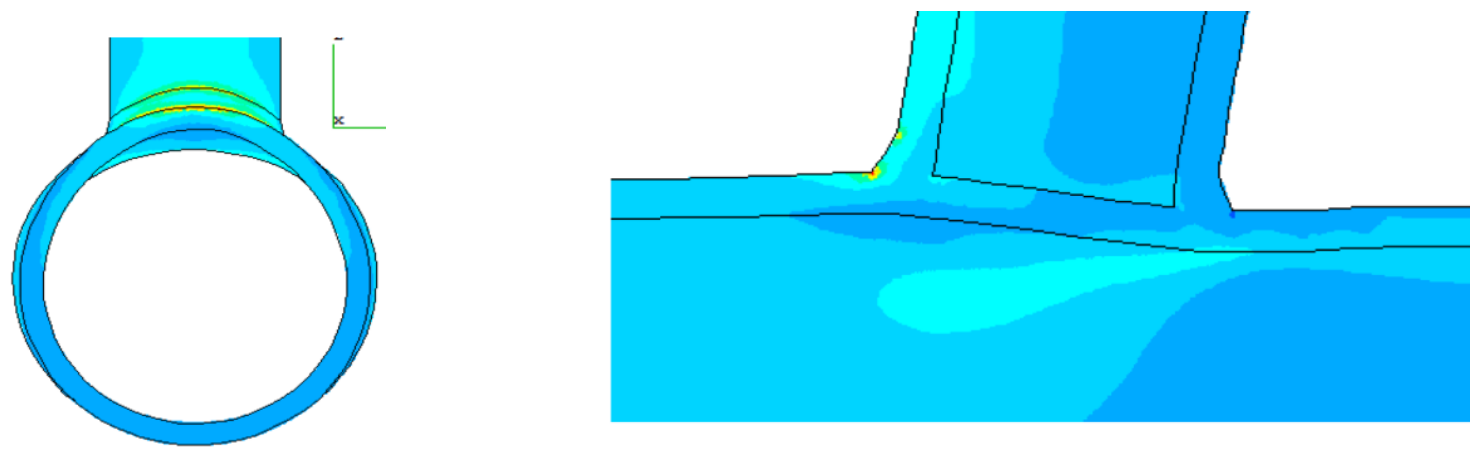

Figure 6. Local deformation

This work has confirmed that stress concentration factors may arise in $\mathrm{K}$-joints up to 2.2, whereas for $\mathrm{T}$ joints the concentration is mostly milder to 1.85 . These figures are taken from a few examples worked out for both Merxem Street and Woluwe Lane bridges.

\subsection{Node stiffening}

The existence of stress concentrations may inspire designers either to generally increase the wall thickness of tubes, both in braces and main arches. However, this would result in uneconomic use of material and poor performance. Increasing the diameter of the main arch tube intensifies the effect of local deformation and certainly lowers the aesthetic character of the structure. The main arch chord is meant to be a strong member, but the braces need sufficient volume as well, since they are essential in the load transfer. In both bridges discussed, the ratio of outward diameters equals 2 , which resulting from [6] probably is an optimum value. Regarding the node stiffening, local reinforcement can be preferred.

Since the effect of welding cannot be eliminated, the single option consists of reducing the local deformation and distortion part of the stresses, as shown in Fig. 6 . One way of obtaining local reinforcement is to supplement the arch tube outside wall with curved reinforcing plates at the exact location of the node. The increase in thickness provides larger cross-sections and is preventing deformations as in Fig. 6. However, this type of reinforcement also decreases the aesthetical value of the tubular arch, since the smooth surface of members is interrupted, much of the pleasant appearance of tubular arches being due to perfect transition of the members.

Hence, internal stiffening of the main arch tube is the optimum alternative. This type of stiffening requires sufficient internal space of the main tube and to weld diaphragms inside the tube. These diaphragms increase the stiffness of the member and are most efficient to prevent the local deformation. The diaphragms may be open or full. The first option is superior for steel conservation.

Fig. 7 shows the internal stiffening for both bridges of Merxem Street and Woluwe Lane. The fundamental difference between them is clearly seen since for the Knode (Fig. 7 left) the diaphragms are located at the intersection of the brace axis with the surface of the main tube. This is the location where the normal member force is transmitted. This arrangement was inspired by the fact that in the truss arrangement bending moments are relatively lower and both meeting brace members are intersecting at the connection. In T-nodes larger bending is expected for frame arrangement (Fig. 7 right). Hence a double diaphragm is used, located exactly below the outside ribs of the brace tube. This should introduce adequately the bending moments in the main arch tube. 

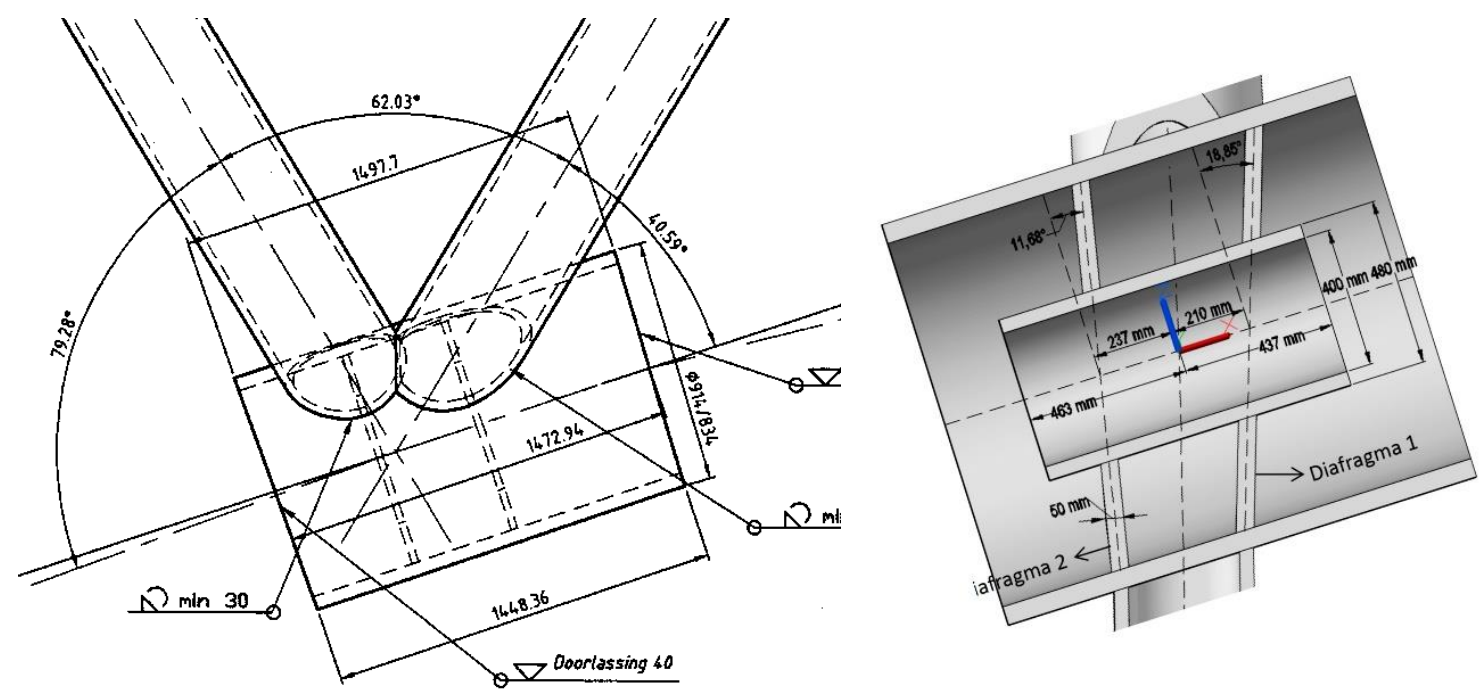

Figure 7. Node stiffening by diaphragms

Since in the case shown in Fig. 7 (right) a second system of brace tubes is provided, to connect the central lower bridge deck to the main arch, the diaphragms are slightly sloping towards this brace. In addition, calculations showed that excessive stress appears at the inner edges of the diaphragms themselves. The stress level can effectively be reduced by short tubes welded to the inner opening of the diaphragms. These small tubes constitute additional flanges to the ribs of the diaphragms. However they are not connected to the main tube and do not disturb the transfer of forces and moments. Fig. 8 shows the preparation of a double diaphragm node. Since nearby butt welds connect the node to the other parts of the member, Fig. 8 may be convincing that the solution is also practical.

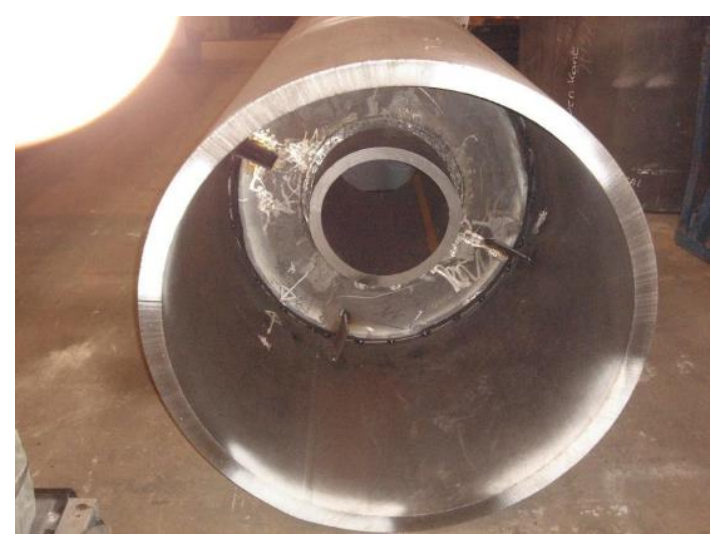

Figure 8. Fabrication of internal stiffening

\subsection{Optimum location of diaphragm stiffening}

A series of numerical simulations and tests [6] confirmed that diaphragm stiffening is really effective to lower stress concentrations, the latter being reduced by factors between 1.7 and 1.8. This corresponds to the evident location as in Fig. 7 the centre plane of the diaphragm corresponding exactly to the centre of the outward rib of the brace tube. However, this does not necessarily correspond to the optimum location for stress concentrations or fatigue resistance. To reduce the former, the location of Fig. 9 shows better performance, the centre plane of the diaphragm corresponding to the outside surface line of the brace tube. This may constitute the optimum location for static loading.

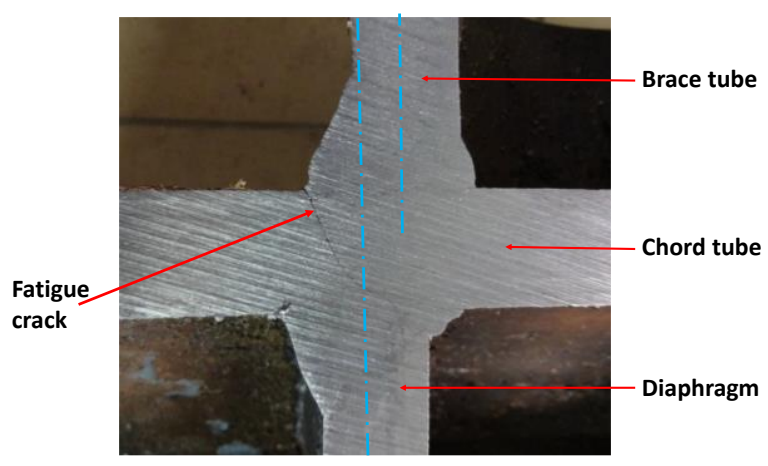

Figure 9. Fatigue crack

However, fatigue resistance may be the main issue for bridges. With the location of Fig. 9 the effects of the opposite welds clearly is too close, causing interference of both possible crack locations, as can be seen in Fig. 9. The actual fatigue resistance is lower than for the evident arrangement. The results show that the largest fatigue resistance is obtained if the centre plane of the diaphragm coincides with the inner surface plane of the brace tube. This avoids the cracking pattern where both welds of the brace to the main tube and the root of the diaphragm weld are interacting.

\section{SCALED TESTS}

The experience of Woluwe Lane bridge has demonstrated that torsional clamping may not entirely be efficient and that small angular rotations may occur, in 
case of clamping by pre-stressing bars [7]. As an alternative, clamping by steel-concrete connectors may be considered. This has recently been applied to 2 bridges, the general idea being to attribute a certain type of connector to resist one or several types of reactions. A picture of this principle is shown in Fig. 10. The strips, welded to the $1.6 \mathrm{~m}$ diameter tube are equipped with headed studs and resist tensile force due to bending, whereas the rings effectively resist normal thrust compression force. Shear is transferred from the steel tube to the concrete abutment by the interior concrete and limitation of contact stresses. As for the torsion moment, it is resisted by both the welded strips and the headed studs. In the case of Fig. 10 the torsion moment was rather low and the torsion stiffness was not a real issue to verify the torsion capacity of a steel tube connected in concrete by 2 different types of connectors. In particular, the strip and headed stud types were to be tested. In addition, it was expected that the tests would give useful indication on how to improve the concept of reinforcement at the connection of the tube and concrete abutment.

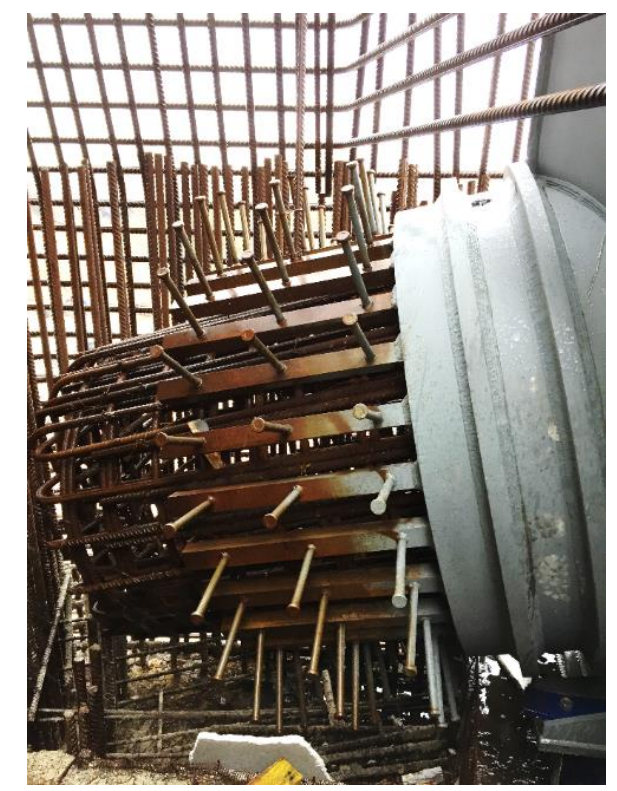

Figure 10. Arch spring with connectors

\subsection{Test aims and setup}

The 3 tests that were conducted are reported here in a summarized version. More details may be found in [8] The aim of the test is to apply a pure torque to a steel tube, encased at its lower end in a concrete block and to determine the failure value of the torque, the rotation angle and the failure pattern. Since these tests were intended as a first approximation and mainly to detect what the failure mechanisms are in this type of connection, the samples were scaled and limited to 3 . Possibly the results may constitute an introduction to a wider program.

The setup, shown in Fig. 11, consists of a truncated parallelogram concrete slab of 1.2 by $1.2 \mathrm{~m}$ and $0.15 \mathrm{~m}$ thickness with a minimum of reinforcing rebars. To reduce the torque magnitude and to use limited auxiliary equipment, the tests are a scaled situation of the real situation by a factor of approximately 10 . Hence, the concrete itself was to be scaled as well and is in fact mortar.

Vertical UPN 160 profiles of S 235 are encased in the concrete slab and are serving as anchorage points to materialize torsion. Finally, each sample included a vertical steel tube 50/8 S 235 welded to a horizontal UPN 80 S 235 profile. The latter allows its connection by load cells to the vertical UPN profiles and thus the application of 2 equal horizontal forces, which act as a torsion moment at the base of the vertical tube.

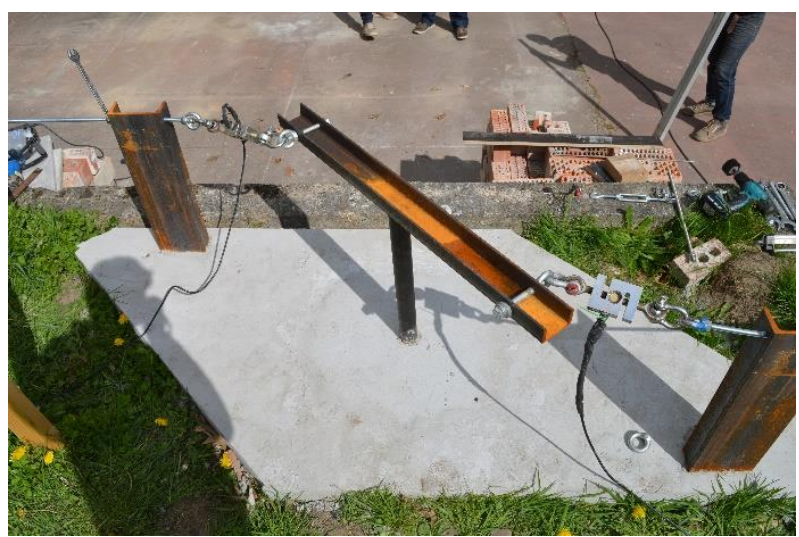

Figure 12. Test setup

\subsection{Test 1 no connectors}

The first test was intended as a trial and also aimed to detect whether any natural bond would exist between the encased part of the steel tube and the concrete slab. Natural bond would certainly influence the resistance of the connection. In addition, it is unsure whether natural bond would simply add to the connector's resistance or have a more complex influence.

Hence, the steel tube end was encased in the concrete at $50 \mathbf{~ m m}$ depth. This corresponds to the diameter of the steel tube. In real structures it is unlikely that a steel tube would be encased to $50 \mathrm{~mm}$ only, although a depth equalling the tube diameter is a common value. Consequently, any natural bound would have been a disturbing factor for further testing.

The code [9] does not recognize any natural contribution to bond. In the present case the concrete strength obtained just before testing was rather low, since temperature was low with frost overnight. This conducted to results for $\mathrm{f}_{\text {ccub150 }}$ from Table 1 and an average resistance of $11.2 \mathrm{MPa}$. This table also includes the values for tests 2 and 3 .

Table 1. Concrete resistance $f_{\text {ccube } 150}(\mathrm{MPa})$

\begin{tabular}{cccc}
\hline Sample & 1 & 2 & 3 \\
\hline Test 1 & 11.4 & 11.0 & 11.2 \\
\hline Test 2 & 17.4 & 16.6 & 17.4 \\
\hline Test 3 & 19.1 & 17.4 & 16.4 \\
\hline
\end{tabular}

During the test it became evident that natural bond was inexistent. The weight of the equipment of load cells, hooks, turnbuckles and chains made the connection fail immediately. 


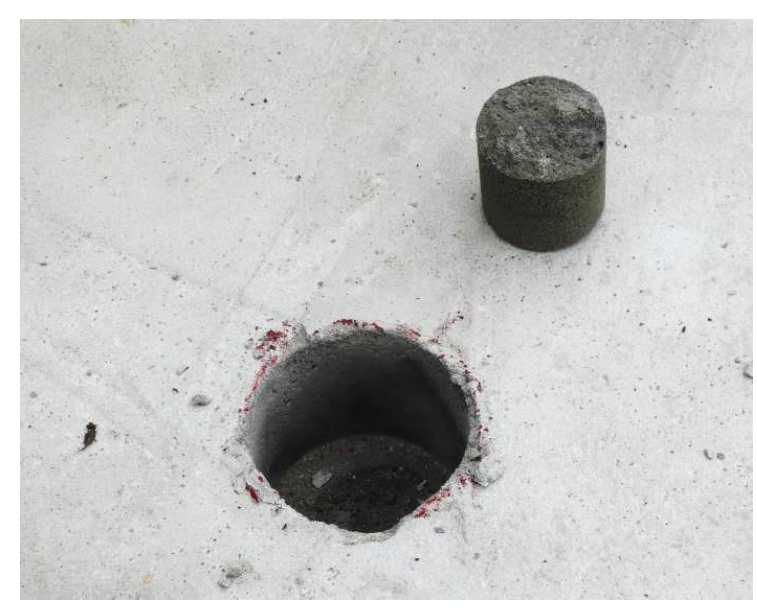

Figure 12. Broken cylinder

The torsion capacity due to bond was limited to $0.051 \mathrm{kNm}$. In addition, after removing the steel tube, a cylinder seemed to have broken from the internal concrete, as can be seen in Fig. 12.

The torsion capacity of this broken cylinder is very low and can be estimated between 0.004 and 0.008 $\mathrm{kNm}$. Obviously, neither the failure of the cylinder nor bond can be of influence to the following tests.

\subsection{Test 2 strip connectors}

In the second test the steel tube end was equipped with $450 \mathrm{~mm}$ long strips with a cross section of $8^{\star} 8 \mathrm{~mm}$. Thus the steel tube reached a depth of $75 \mathrm{~mm}$, since the last $25 \mathrm{~mm}$ was also encased in the concrete slab. This corresponds to the arrangement of Fig. 10, without stud connectors.

The connection should have failed for a design value of the torque equalling $0.613 \mathrm{kNm}$. The latter corresponds to yielding of the strips due to shear, taking into account the yield stress of $235 \mathrm{MPa}$. However, the yielding does not necessarily correspond to failure. It introduces large deformation and may initiate other failure mechanisms. The graph of Fig. 13 shows the relation of the angular rotation versus torque.

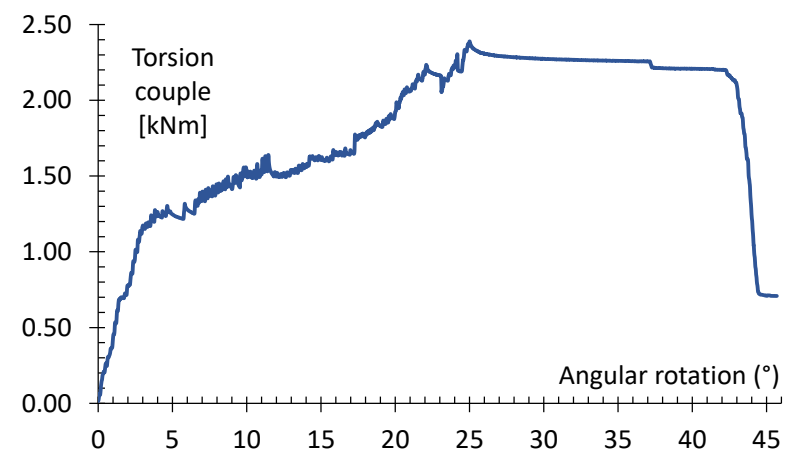

Figure 13. Load-time diagram test 2

In this diagram several failure steps can be found. They will be analyzed further. Already one may see that after the first linear phase, the curve deviates from the linear part and becomes flatter for a value of the torsion moment of about 1.3. This demonstrates that a new mechanism must be reached. From a torsion moment of $1.7 \mathrm{kNm}$ the curve again becomes steeper and reaches a maximum for a torque of $2.39 \mathrm{kNm}$. After reaching the maximum the curve continues first with a horizontal part and rapidly growing angular rotation and finally descends steeply. The conclusion must be that 2.39 $\mathrm{kNm}$ is the failure moment.

Some observations were made after this test. As Fig. 14 shows, the strips were excessively bent, although no real sign of cracking or fracture was found at the strip base. This demonstrates that failure of the steel strips alone did not occur during the test. In addition, after removal of the steel tube, the strip ends seem to have been fixed in the concrete, as can be seen in Fig. 15. Apart from some crushing at the edges, there is but little damage to these prints. This might suggest that a bending mechanism of the strips has existed, consisting of a support at the concrete side and a certain degree of clamping at the end of the steel tube.

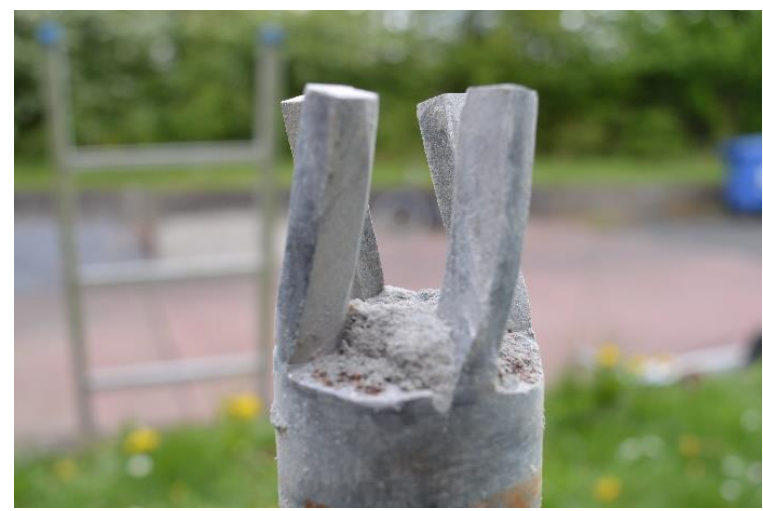

Figure 14. Excessive bending of strips

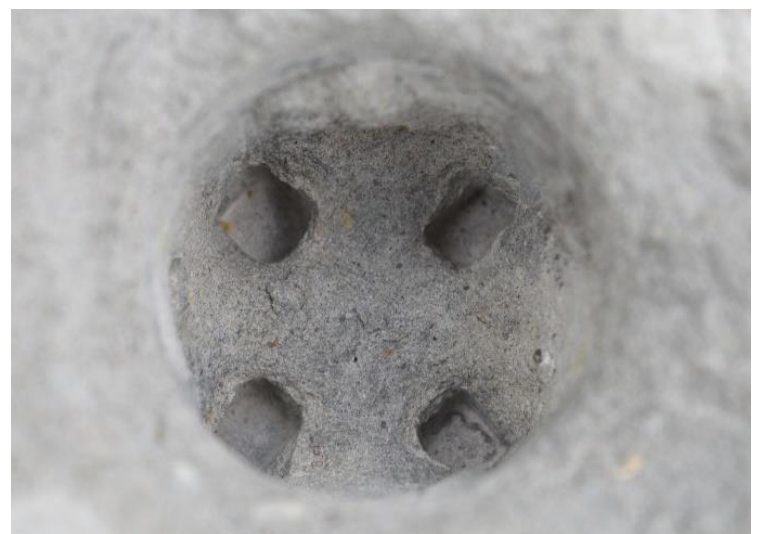

Figure 15. Prints made by strips

\subsection{Test 3 stud connectors}

In the $3^{\text {rd }}$ test, an identical tube is equipped with 2 headed stud connectors. The bolts, simulating studs, were welded to the tube and were intended to be encased at a depth of $25 \mathrm{~mm}$. A detailed picture of the bolts and tube can be seen in Fig. 16. The total length of the bolts equals $60 \mathrm{~mm}$, including the head of $13 \mathrm{~mm}$. The steel grade differs from classical stud connectors, albeit the value of $f_{u}=400 \mathrm{MPa}$ is close to the usual 420 MPa. 
The predicted value of this connection was based on either the crushing of the surrounding concrete or shear of the connector shaft. As for the torsion moment, the lever arm would be determined by the tube diameter. Thus the predicted value reached $0.98 \mathrm{kNm}$. As for the previous test, a diagram of the torque versus the angular rotation was determined. The graph is shown in Fig. 17.

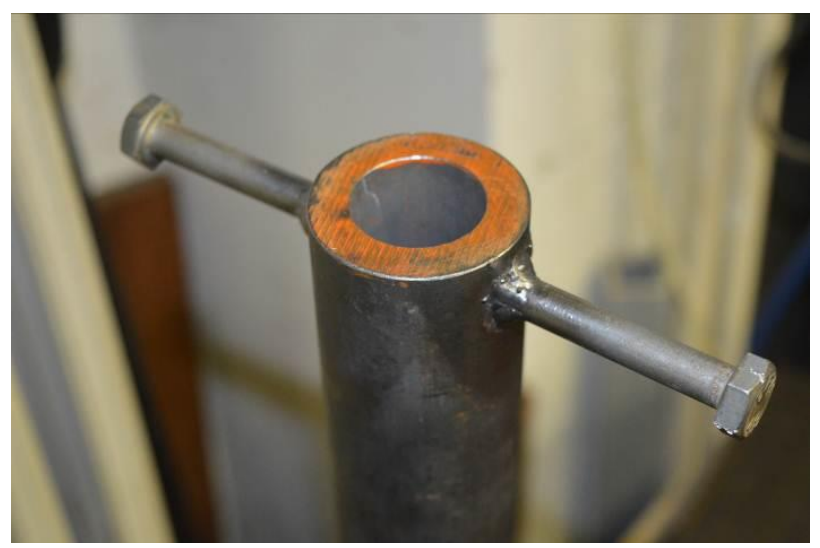

Figure 16. Stud connection

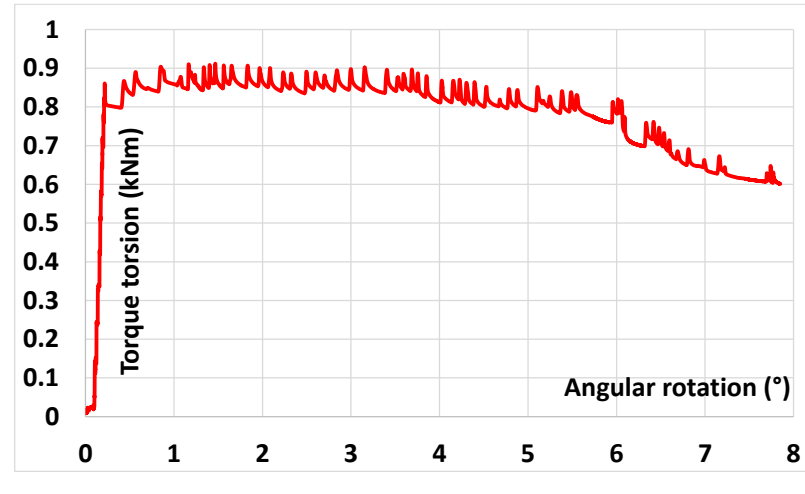

Figure 17. Torque versus angular rotation

In the first part of the diagram a linear relation of the torque with the angular rotation is ending at the maximum value of the torsion moment of $0.825 \mathrm{kNm}$. This is definitely lower than the predicted value. From there the curve starts descending while the rotation increases rapidly. The torsion moment decreases till it reaches a

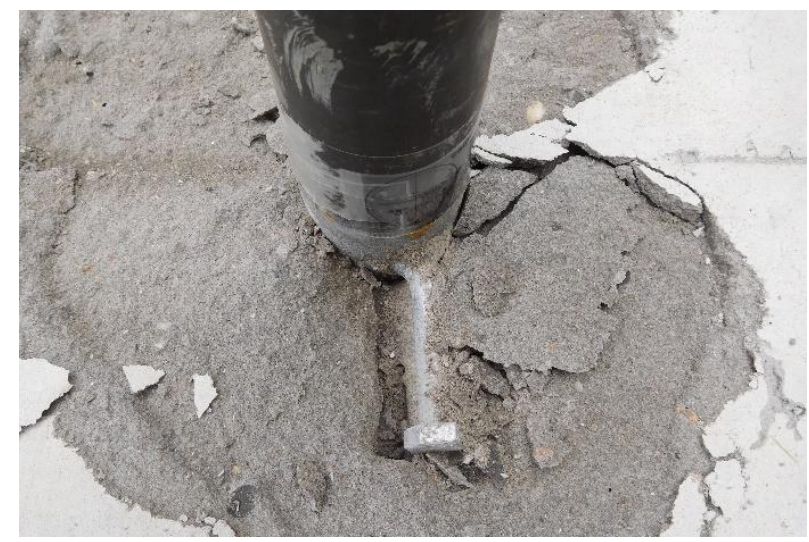

Figure 18. Concrete failure of stud connection value of $0.7 \mathrm{kNm}$. During this phase cracks start appearing at the concrete surface and the latter is spalling. After this phase the curve further descends more rapidly and apparently a new mechanism is starting. The rotation can further increase for a lower value of the torque, while the concrete spalling is further increasing. Finally, cracks become general and the torque drops from a value of $0.55 \mathrm{kN}$ at the end of the curve. This is the final failure point. After removal of the spalled concrete the end situation becomes clear as in Fig. 18. The studs are not broken, but heavily bent. There is no apparent cracking of any of the steel parts and thus the concrete part must have failed.

\section{ANALYSIS OF TEST RESULTS}

\subsection{Strip connectors}

The aim of this section is to provide acceptable explanation of the experimental results and thus try to derive a failure condition and the robustness of both types of connections. Obviously, these tests do not pretend completeness and the main aim is to detect the failure mechanisms.

The first discontinuity in the diagram of Fig. 13 corresponds to $T=1.327 \mathrm{kNm}$. Considering composite bending as well as the fact that the ends of the strips have been fixed at the lower parts of the concrete, as seen in Fig. 15, the loading condition of the strips may be considered similar to a one-side clamped and oneside simply supported beam.

Assuming such a scheme, the largest bending moment appears at the clamped edge. The scheme may be considered as a RC-beam, the reinforcement being equal to the steel strip. As for the concrete cross-section, this may have a height of $8 \mathrm{~mm}$, as the steel strip and a width of 3 -times this value. These characteristics are a reasonable assumption, given the geometric parameters of the connection.

The resisting bending moment of the RC-beam may now be determined by assuming the concrete stress in the 8 * $24 \mathrm{~mm}$ area to reach $3 \mathrm{f}_{\mathrm{cm}}$, according to the appropriate code [10] the strength value for local contact compression. This resisting bending moment corresponds to a value of the shear force of $15.8 \mathrm{kN}$ for each strip and thus a torsion moment of $T=1.327 \mathrm{kNm}$. This almost exactly corresponds to the summit of the first linear part of the diagram of Fig. 13.

From these data one may conclude that the first discontinuity in the diagram is due to reaching concrete compression failure of the RC-section of a strip and the surrounding concrete. In these conditions, the actual contact stress equals may still increase before reaching $3 \mathrm{f}_{\mathrm{cm}}=31.6 \mathrm{MPa}$. This also applies to the steel stress, since its value reaches $184.5 \mathrm{MPa}$, well below the yielding stress.

However, the slope of the diagram now reduces, while the torsion moment can still increase. The actual concrete contact stress can still rise, until the concrete compression equals $3 \mathrm{fcm}_{\mathrm{cm}}$. At this point the torsion moment equals $1.727 \mathrm{kNm}$, which corresponds exactly to the end of the second part of the diagram of Fig. 13. Hence, from this point the concrete at the concave side of the excessively bended strips has failed laterally. The 
diagram then shows again a steeper third part of the curve.

As mentioned before, the steel stress of the RCcross section can still be increased up to the failure value of $400 \mathrm{MPa}$. For the one sided clamped and one side simply supported beam this occurs for a total lateral force of $21.67 \mathrm{kN}$, corresponding to a torsion moment of $2.39 \mathrm{kNm}$, which corresponds well to the maximum value of the diagram of Fig. 13.

Although various assumptions have been made, it is believed that all 3 characteristic points of the diagram of Figure 14 are thus explained and that composite action of the strips, due to heavy lateral compression and friction, is the evident way to explain the results of test 2 . At any rate, the failure torsion moment of $2.39 \mathrm{kNm}$ is considerably larger than the torque of $0.615 \mathrm{kNm}$ which would be the yield point of the strips. Hence the connection would surely have failed earlier, should there not be any interaction with the encasing concrete.

\subsection{Headed stud connectors}

As for the strip connectors, the 3 characteristic points of the torsion moment versus angular rotation diagram are being assessed. However, the diagram of Fig. 17 is completely different from the one of the strip connectors. The first linear part stops at the maximum of the curve and must be considered as the failure load. This maximum value of the curve corresponds to a torque of $0.83 \mathrm{kNm}$. According to the appropriate code [3] the shear resistance of the studs is the lower of both values $\mathrm{P}_{\mathrm{u} 1}$ and $\mathrm{P}_{\mathrm{u} 2}$ determined as:

$P_{\mathrm{w} 1}=\frac{0.8 f_{\mathrm{u}} \pi d^{2}}{4}$

$$
P_{\mathrm{w} 2}=0.29 \alpha d^{2} \sqrt{f_{c m} E_{c m}}
$$

The second formula, corresponding to concrete failure proves to be determining and renders a failure shear force of $19.575 \mathrm{kN}$ or a torsion moment of 0.98 $\mathrm{kNm}$, exceeding the maximum value of the curve. Obviously, the connection has less resistance.

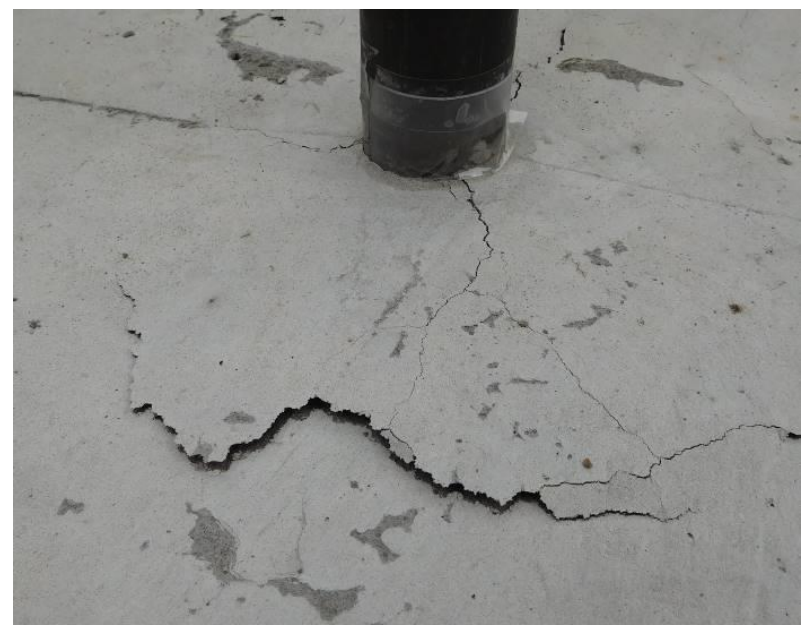

Figure 19. Early concrete surface cracking
In section 5.4 the surface cracking at early stage during the test was mentioned. This is shown in Fig. 19. This type of cracking may be explained by local compression introduced through the stud shaft and subsequent splitting of the upper part of the concrete. This is in accordance with the code [9] since the equations (1) and (2) are no longer valid when studs are arranged in a way that splitting forces occur in the direction of the slab thickness, unless reinforcement is provided. Hence, since no reinforcement was interfering with the cracks, the studs should have been located at larger depth in the concrete slab.

The limitation of splitting reduces the maximum shear of stud connectors and is expressed by equation for $\mathrm{T}_{\text {uspl }}$ (3).

$$
T_{\text {wspl }}=\sqrt{2} \eta f_{\text {cm }} r_{\text {stwd }} l_{\text {act }} D
$$

In this $\eta$ is a geometric factor, estimated at 1.14 and lact is the active length of the stud for splitting. The latter was estimated at $53 \mathrm{~mm}$. In equation (3) the value of $D$ must be taken as the tube diameter plus the connector shaft length. The ultimate torsion moment takes the value of $0.825 \mathrm{kNm}$ and complies with the experimental value.

Once the concrete has been split entirely, roughly half of the encasement subsists and it may be assumed that the connectors are still active. Again, it must be concluded that at this stadium a composite action must exist. Should the studs act independently, the crosssection yields for a bending moment of

$M_{y}=\frac{4 R^{3} f_{y}}{3}$

The maximum shear force corresponding to the bending moment (4) may be calculated. It must be multiplied by the tube diameter plus the length of a single stud to obtain the corresponding torsion moment of $0.489 \mathrm{kNm}$. This is considerably lower than the second characteristic point of the curve. The value of $\mathrm{T}=$ $0.71 \mathrm{kNm}$ corresponds almost exactly to the ultimate bending moment for a $\mathrm{RC}$ section, the rebar being the stud cross-section and the concrete part being an area of $30 * 10 \mathrm{~mm}$, in a similar manner as for strip connectors.

The end of the curve corresponds to a large angular rotation as can be seen in Figure 19. The stud heads are still encased in the concrete and are able to resist a tensile force corresponding to the yield stress of the studs. Taking $\mathrm{f}_{\mathrm{y}}=320 \mathrm{MPa}$ this results in the value of $\mathrm{T}=0.533 \mathrm{kNm}$.

\subsection{Deformation capacity}

In the diagram of Fig. 20 both curves have been combined and limited to the lowest values of the angular rotation. The difference between both curves is striking, since the rotations are totally different.

From the data the specific rotation angle can be determined. They have been summarized in Table 2. The table also indicates that the experimental torsion angle (in $\mathrm{rad} / \mathrm{m}$ ) is measured from the concrete surface to the location of the stud stiffness GC, assuming the specific torsion or the connection with the strip. 


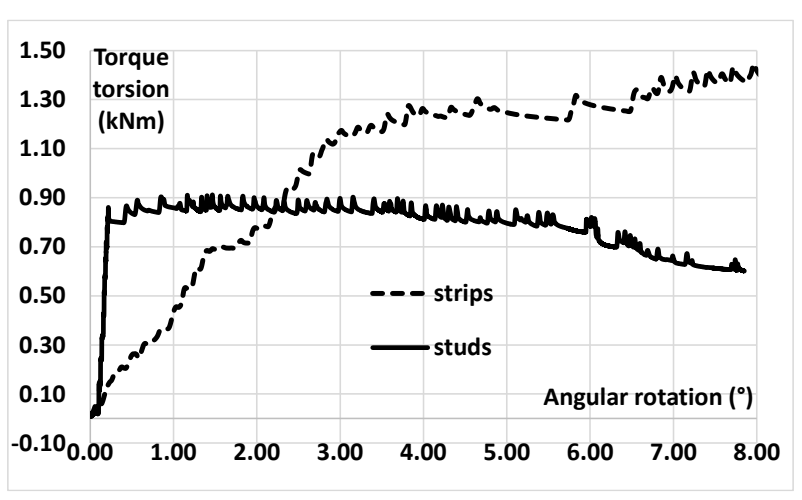

Figure 20. Diagrams for strips and studs combined

Table 2. Torsion angular rotations

\begin{tabular}{lcc}
\hline Connector type & Strips & studs \\
\hline Angle Rad/kNm & 0.0370 & 0.00872 \\
\hline $\begin{array}{l}\text { Torsion stiffness } \\
\text { kNm } 2 / \mathrm{rad}\end{array}$ & 0.5411 & 2.8685 \\
\hline
\end{tabular}

Table 2 confirms that strip connectors, reputed to be of the stiff type are more flexible than studs, which are generally considered as flexible. In addition, the values may be compared to $\mathrm{GC}=37.6 \mathrm{kNm}^{2}$ of the steel tube, which is respectively 70 -times and 13-times stiffer than the strip- and the stud connection.

\subsection{Arch spring rotation}

The Moerbrug bridge, near to Bruges, is a steel tied arch, with springs located below the chord members. The connection to the concrete abutments is similar as in Fig. 10, a combination of strip and stud connectors. Unfortunately, as shown in Fig. 21, the connectors are located inside the steel tube. Hence, their resistance is exclusively due to concrete strength.

During casting of the bridge deck, the temporary bracing, connecting both arches was removed too soon. This temporary bracing can be seen in Fig. 22. Due to this prematurely removal, the concrete casting resulted in lateral displacement of the arch tops by $40 \mathrm{~mm}$. The latter cannot be explained by the missing bracing alone, since calculations show that the lateral displacement should be limited to $21.04 \mathrm{~mm}$.

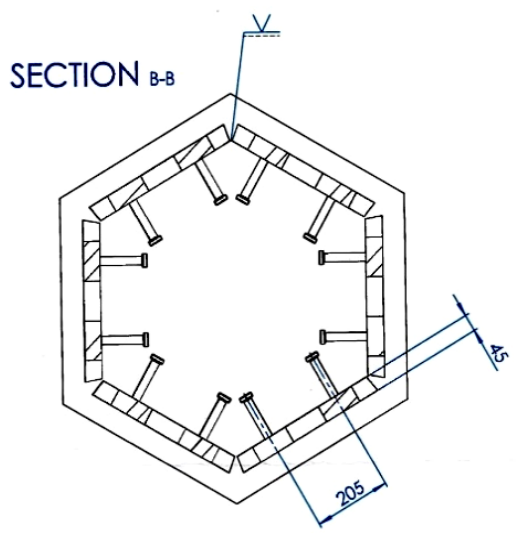

Figure 21. Arrangement of connectors
Several causes for the excessive deformations of the arch tops can be considered. One of them is the lack of torsion stiffness. Hence, it was suspected the lack of torsion stiffness, possibly combined with lateral movement of the connection, may be a source of excessive deformation.

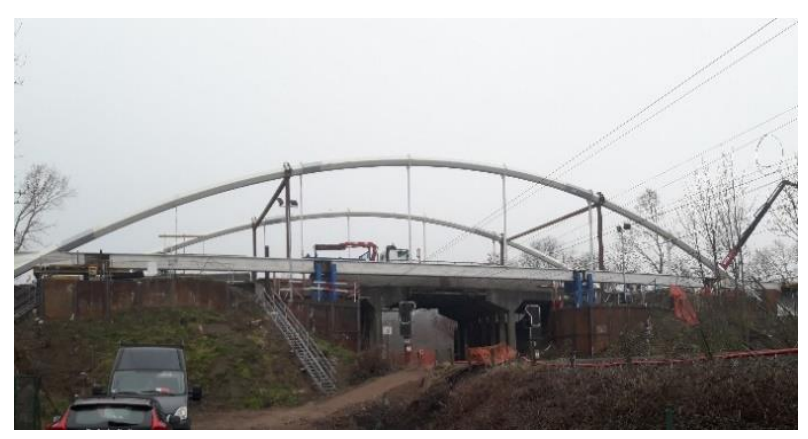

Figure 22. Bridge with temporary bracing

For the loading case that caused the lateral displacements, the torsion moment equals $130.4 \mathrm{kNm}$. Should the axial rotation of the arch springs not be prevented, it takes a value of $0.0026 \mathrm{rad}$. If the angular rotation of stud connection is scaled to this case by the parameters of stud diameter, active length, concrete strength, tube diameter and number of studs, a value of the rotation of $0.000244 \mathrm{rad}$ is found. However, the torsion may also result in the separation of an internal cylinder as in Fig. 3. If the torque for breaking this cylinder is also scaled to the bridge size, the failure value corresponds to $15.46 \mathrm{kNm}$.

These data lead to the conclusion that the internal studs have little contribution to the arch rotational clamping. Hence, the strips encased in the concrete abutment have the largest contribution to the limitation of arch spring rotations.

According to similitude law, the rotation stiffness value for strips from table 2 can be scaled to the actual bridge, including the parameters of length $t$, diameter $D$, concrete strength $f_{\mathrm{cm}}$ and number $\mathrm{N}$ of strips, according to $(5)$ ( $p$ is for real structure, $m$ for model)

$\theta_{p}=\theta_{m} T_{p} \frac{t_{\text {strip m }} D_{m} f_{c m m} N_{m}}{t_{\text {strip p }} D_{p} f_{c m p} N_{p}}$

the angular rotation becomes $0.008637 \mathrm{rad}$, which is larger than if there would be no torsion clamping at all. This indicates that the connection with internal studs may be ineffective for torsion.

\section{CONCLUSIONS}

It was implied that the load carrying capacity of tubular arch bridges with truss arrangement of the brace tubes connecting the upper bridge deck to the arch is larger than the equivalent frame arrangement. This is due to lower normal compression force at the arch crown and lower clamping moment at the springs for the truss alternative. Both of these characteristics also apply to the brace tubes. Equivalence of the load carrying capacity is reached if 25 to $30 \%$ more steel is used for the frame alternative. 
However, the truss alternative requires the use of Knodes, which are definitely more complicated to fabricate than T-nodes and certainly more costly. In addition, the stress concentrations around K-nodes are slightly higher than for T-nodes. Hence, the choices between both alternatives of truss and frame arrangement are mostly depending on the aesthetic value of the bridge.

Since the nodes of tubular arch bridges are equally important as is the brace arrangement, and in order to reduce stress concentrations, an optimal location of internal diaphragm has been derived. This location may vary if fatigue resistance proves to be an important issue for the bridge.

Three scaled tests, applying torsion to a steel tube, encased on a sufficiently large concrete slab is of course a limited number to draw general conclusions. The number of tests should be considerably larger and some characteristics of the test including headed studs should be modified. In addition, the combination of various types of connectors should also be considered. Nevertheless, the 3 tests have demonstrated or confirmed some properties of strip and stud connectors, subjected to torsion.

Natural bond does not contribute to the connection of steel and concrete, as shown by the result of the first test, which obviously also served for improving the setup and equipment.

The second test has demonstrated that from the first loading a composite action of steel and concrete must exist. Three successive mechanisms for resistance of this type of connector were found. In addition, the strip connection is rather flexible for torsion and does not really act as perfect clamping, since it appeared to be 70-times weaker than the torsion stiffness of the steel tube.

The third test showed that headed studs need to be supplemented by rebars, since failure occurred prematurely, due to concrete splitting, starting at the contact area of the stud shaft. This is easily avoided by normal reinforcement. The torsion stiffness of the connection is distinctly higher compared to the previous type.

In relation to the excessive lateral displacement of the arches of the Moerbrug bridge, during concrete casting, an attempt was made to relate it to torsional stiffness of the arch spring connection. The result indicates that the studs inside the arch closed section are probably ineffective. Any torsion stiffness must be provided by the strips. However, scaling of the test results demonstrates that the arch spring almost behaves as a free torsion condition.
Further experimental research would be welcomed to improve knowledge about this torsion connection and might perhaps result in establishing more reliable data about the torsion stiffness of steel bridge superstructure in concrete abutments.

\section{REFERENCES}

[1] Jarmay, K., Farkas, J. "Mechanics and design of tubular structures”. Springer Wien-New-York 1998.

[2] Van Bogaert, Philippe. (2006). Design and Construction of the Merxem Bridge - A Single Tubular Arch. Proc. 6th Int. Symposium Steel Bridges (pp. 56-65). ECCS/CECM/EKS

[3] Van Bogaert, Ph, De Pauw, B "New railway connection below Brussels Airport", Proc. $17^{\text {th }}$ IABSE Congress Creating and Renewing Urban Structures IABSE Chicago, 2008 pp 280-281.

[4] Van Bogaert, Ph, "Frame effects in hangers of steel tied arch bridges". Proc Eurosteel $20116^{\text {th }}$ Eur Conf on steel and composite structures. ECCSBudapest 2011 pp 1383-1388

[5] Stael, D, De Backer, H, Van Bogaert, Ph, 'Determining the SCFs of tubular bridge joints with an alternative method', Journal of Constructional Steel Research, Vol. 101, pp. 1-8, 2014

[6] Stael, D. Improving the fatigue resistance of welded connections of tubes for bridges by diaphragm stiffening. PhD Dissertation, Ghent University 2014

[7] Van Bogaert, Ph. Torsion clamping by prestressing bars of an arch bridge in concrete abutment. Proc. FIB symposium Tel Aviv, Engineering a concrete future: technology, modeling \& construction $2013 p$ 245-248

[8] Van Bogaert, Ph, Schotte, K and De Backer, H. Post failure torsion capacity and robustness of encased tubular arch spring connections. Proc. IALCCE 2018 Ghent 2018 pp 2231-2238

[9] EN 1994-1-1 2004. Eurocode 4 Design of composite steel and concrete structures - Part 1-1: General rules and rules for buildings (+AC 2009). European Committee for Standardisation. Brussels.

[10] EN 1992-1-1 2004. Eurocode 2 Design of concrete structures - Part 1-1:General rules and rules for buildings (+AC 2008). European Committee for Standardisation. Brussels 


\section{BRACE ARRANGEMENT, NODE STIFFENING AND CONNECTION OF SPRINGS OF STEEL TUBULAR ARCH BRIDGES MIHA TOMAŽEVIČ}

\section{Em Philippe VAN BOGAER}

Three characteristics of steel tubular arch bridges are being discussed. The brace members, connecting the main chord tube to an upper concrete or composite deck can be arranged either as triangular truss members, or as rigid node vertical or slightly sloping frame members. As can be expected, the former arrangement results in lower bending of the arch chord and lower compression near its centre. However, the number of brace tubes for triangular arrangement is twice as much as for the frame system. In addition, the nodes of the truss system necessarily join at least 4 tubes and are of the K-type. The latter are more complicated to design and to fabricate than T-nodes, used in the frame arrangement.

Fatigue resistance of welded tubular nodes is rather low. Should the chord diameter be sufficiently large, internal diaphragm stiffeners can be provided, thus increasing considerably the fatigue resistance. Both numerical and experimental research demonstrates that an optimal location of the diaphragms can be found. However, this optimum location does not necessarily correspond to the minimum of stress concentrations.

Most springs of steel tubular arch bridges are rigidly connected to a concrete abutment. Generally prestressing bars are used to achieve this. Unfortunate experience has shown that this connection may still be too flexible to prevent axial rotation due to torsion. The alternative of using various connectors has been implemented in few bridges. The torsion resistance of such a connection has been assessed in 3 scaled tests. The results have given more insight into the mechanism of torsion connection and results in experimental values of the torsion stiffness. The preliminary conclusion of this research indicates that stud connectors show larger stiffness than strips, which is a rather unexpected outcome.

Keywords: steel tubular arch bridge, fatigue resistance, arch spring torsion, strip stud connectors, tubular node stiffening, rotation stiffness

\section{APSTRAKT}

\section{RASPORED UKRUĆENJA, UKRUĆENJE ČVOROVA I VEZA S KRAJNJIM OSLONCIMA ČELIČNIH CEVASTIH LUČNIH MOSTOVA}

\section{Em Philippe VAN BOGAER}

Razmatraju se tri karakteristike cevastih lučnih mostova. Elementi ukrućenja, koji povezuju glavnu pojasnu cev s gornjom betonskom ili spregnutom pločom mogu biti postavljeni ili kao trougaone rešetke, ili kao ram s krutim čvorovima i vertikalnim ili blago nagnutim elementima. Kao što se može očekivati, prva postavka daje manje savijanje pojasa luka i manji pritisak blizu njegove sredine. Međutim, broj cevastih ukrućenja za trougaonu postavku dvostruko je veći u odnosu na ramovski sistem. Pored toga, čvorovi rešetkastog sistema nužno povezuju bar četiri cevi i oni su tipa „K”. Ovo potonje je kompikovanije za projektovanje i izvođenje od T-čvorova korišćenih u ramovskoj postavci.

Otpornost na zamor čvorova zavarenih cevi veoma je niska. Ako bi prečnik pojasa bio dovoljno velik, unutrašnja ukrućenja u vidu dijafragmi mogu se ugraditi i tako značajno povećati otpornost na zamor.

I numerička i eksperimentalna istraživanja pokazuju da je moguće naći optimalni položaj dijafragmi. Međutim, ovaj optimalni položaj ne mora nužno odgovarati minimalnim koncentracijama napona.

Većina krajnjih oslonaca cevastih lučnih mostova kruto je vezana za betonske oslonce. Generalno se koriste prednapregnute šipke da bi se ovo postiglo. Negativna iskustva su pokazala da ova veza ipak može biti previše fleksibilna da bi sprečila aksijalnu rotaciju usled torzije. Alternativa tome bila je upotreba različitih konektora koja je primenjena kod nekoliko mostova. Otpornost na torziju ovakvih konektora ocenjivana je putem tri opita u smanjenoj razmeri. Rezultati su pružili više uvida $u$ mehanizam torzione veze $i$ dobile su se eksperimentalne vrednosti torzione krutosti. Preliminarni zaključak ovog istraživanja ukazuje na to da konektori s moždanicima iskazuju veću krutost nego trake, što predstavlja prilično neočekivan ishod.

Ključne reči: čelični cevni lučni most, otpornost na zamor, torzija oslonca luka, konektori $s$ trakastim moždanicima, ukrućenje cevnog čvora, rotaciona krutost 